\title{
An Attempt to Evaluate the Quality of Clinical Trial Data by the Investigational Medical Institution Itself : Survey of Quality of Clinical Trial Data from the Source Documents Verification (SDV) Viewpoint
}

\author{
Kazushi OHASHI ${ }^{* 1}$ Ryoko ASO*1 Emiko OSUGA*1 \\ Hiroe NARA*2 and Shihoko OTA*2
}

(Received on June 15, 2001)

*1 Clinical Pharmacology Center, Nippon Medical School

1-1-5 Sendagi, Bunkyo-ku, Tokyo 113-8602, Japan

*2 Office of Institutional Review Board for Drugs, Nippon Medical School

The aim of this study was to look at the clinical trials from the viewpoint of medical institution's own data management. From source documents verification (SDV) from 33 clinical trials (126 cases) carried out in Nippon Medical School Hospital between June 1999 and July 2000, the verification rate, inconsistency rate and occurrence state of deviation were surveyed.

In the SDV of 126 cases, the mean verification rate was $97.5 \pm 4.0 \%$ [mean $\pm \mathrm{SD}$ (range: $85.8 \sim 100 \%$ ) ]. The data with the lowest verification rate was on items for "evaluation" (82.9\%) followed by "others", "side effects/adverse events" and "withdrawal/dropout". The major reason for the impossibility to verify was due to the fact that investigators entered the records directly to CRF without recording on to medical charts (no statement was made to regard data entered to CRF as source data). Other reasons were due to the monitor's inappropriate interpretation of the medical chart, insufficient preparation of source documents for SDV. There was no case which source data was missed.

Among the 26,628 data verified, inconsistency was found between CRF and the source documents in 333 data [ $1.7 \pm 2.3 \%$ (range : $0 \sim 8.1 \%$ )]. Inconsistency was caused mainly by inaccurate entering of data to CRF and by incomplete data of CRF due to omission of entry. Other reasons were miscalculation, misspelling, and contradiction between source documents.

In 126 cases 68 deviations were found. The majority was that laboratory tests had not been carried out. Serious deviations observed were those of exclusion/inclusion criteria, inappropriate informed consent, and omission of the evaluation.

Data error observed in this survey were considered to be within the acceptable range. We conclude that by reviewing the verification rate, the inconsistency rate and the occurrence state of deviation as measurements of quality of clinical trial data, each medical institution can achieve their own data management.

Key words : verification rate, inconsistency rate, deviation, and data management

*1 日本医科大学臨床薬理センター ₹ 113-8602 東京都文京区千駄木 1-1-5

*2 日本医科大学薬物治験審査委員会事務局 


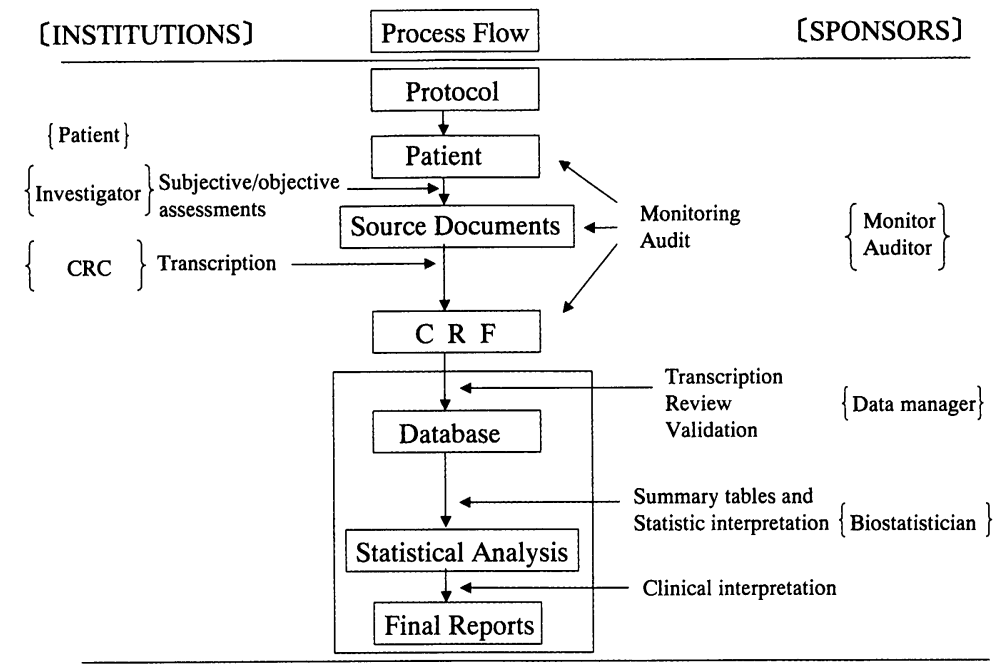

Fig. 1 Multiple steps of data collection and process flow to final reports in a clinical study

\section{Introduction}

The aim of this study was to examine clinical trials from the viewpoint of data management. Confirmation of whether the data reported from the investigator to the sponsor is accurate and reliable is a fundamental requirement of Good Clinical Practice (GCP) ${ }^{1}$. Monitors in the sponsor side carry out this confirmation through source documents verification (SDV) process. However, it is the medical institution that collects data through the clinical trial and prepares case report forms (CRF) based on the data (Fig. 1). Therefore, it is of significant importance for the medical institution to have a self-check function to evaluate the quality of the clinical trial by checking whether the data reported from the investigator to the sponsor was accurate and complete. In Nippon Medical School we tried to test the self-check system through the model project ${ }^{2}$ using SDV by direct access to medical charts from October to December 1997, just before the full enforcement of new GCP. During that process, the percent- age of the amount of data verifiable in SDV to the total amount of data in CRF was calculated as the verification rate. A verification rate of $86.4 \pm 12.9 \%$ [mean $\pm \mathrm{SD}$ (range : 63.7 99.7\%)] was achieved at that time (Table 1). For clinical trials 2 years after the first survey, the same survey was carried out to find which measurements of quality are appropriate to monitor the change in the level of clinical trials. The purpose of this survey was to identify the factors to be taken into account in order to allow the medical institution itself to execute an effective and proper clinical trial management system and to determine the future direction to proceed.

\section{Method}

For the result of SDV from 33 clinical trials (126 cases) carried out in Nippon Medical School Hospital between June 1999 and July 2000 , the following matters were reviewed by checking of $\mathrm{CRF}$, inquiring of the monitor in charge and IRB survey by the members of IRB office carried out simultaneously with SDV in 
Table 1 Percentage of Amount of SDV-possible Data to All Amount of Data in CRF as Verification Rate

\begin{tabular}{|c|c|c|c|c|c|c|c|c|}
\hline & Drug & Disease & Stage & $\begin{array}{l}\text { Total data } \\
\text { of } \mathrm{CRF}\end{array}$ & $\begin{array}{l}\text { SDV-po } \\
\text { (verifica }\end{array}$ & $\begin{array}{l}\text { le Data } \\
\text { nate\%) }\end{array}$ & $\begin{array}{r}\text { SDV-i1 } \\
\text { D }\end{array}$ & $\begin{array}{l}\text { ossible } \\
\text { a }\end{array}$ \\
\hline 1 & Antiarrythmic & VPC & late nhase II & 310 & 285 & $91.9 \%$ & 25 & $8.1 \%$ \\
\hline & (Class Ib) & VPC & late pnase in & 310 & 284 & $91.6 \%$ & 26 & $8.4 \%$ \\
\hline 2 & $\begin{array}{l}\text { Immunosuppres- } \\
\text { sive drug }\end{array}$ & Aplastic anemia & phase III & 94 & 89 & $94.7 \%$ & 5 & $5.3 \%$ \\
\hline & & & & 405 & 259 & $64.0 \%$ & 146 & $36.0 \%$ \\
\hline 3 & Antiemetics & Reflux esophagitis & early phaseII & 405 & 258 & $63.7 \%$ & 147 & $36.3 \%$ \\
\hline & & & & 405 & 348 & $85.9 \%$ & 57 & $14.1 \%$ \\
\hline 4 & $\begin{array}{l}\text { Antiarrythmic } \\
\text { (Class Ic) }\end{array}$ & VPC & phase III & 343 & 281 & $81.9 \%$ & 62 & $18.1 \%$ \\
\hline 5 & $\begin{array}{l}\text { Specific hyposen- } \\
\text { sitization thera- } \\
\text { peutic drug }\end{array}$ & $\begin{array}{l}\text { Nasal allergy } \\
\text { (Cedar induced) }\end{array}$ & phase II & 249 & 242 & $97.2 \%$ & 7 & $2.8 \%$ \\
\hline 6 & Anticancer agent & Cancer & phase I & 82 & 71 & $86.6 \%$ & 11 & $13.4 \%$ \\
\hline 7 & Cardiac failure & Acute heart failure & early phaseII & 539 & 494 & $91.7 \%$ & 45 & $8.3 \%$ \\
\hline 8 & $\begin{array}{l}\text { Brain metabolic } \\
\text { stimulant }\end{array}$ & Cerebral thrombosis & late phase II & 862 & 603 & $70.0 \%$ & 259 & $30.0 \%$ \\
\hline 9 & $\begin{array}{l}\text { Consciousness } \\
\text { stimulant }\end{array}$ & $\begin{array}{l}\text { Cerebral infarction } \\
\text { (acute stage) }\end{array}$ & late phase II & 750 & 720 & $96.0 \%$ & 30 & $4.0 \%$ \\
\hline 10 & Anticancer agent & Non small cell lung & late phase II & 709 & 707 & $99.7 \%$ & 2 & $0.3 \%$ \\
\hline & 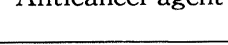 & cancer & & 383 & 381 & $99.5 \%$ & 2 & $0.5 \%$ \\
\hline & & Total (mean \pm sd) & & $429.6 \pm 258.9$ & 86.4 & $2.9 \%$ & 13.6 & $2.9 \%$ \\
\hline
\end{tabular}

order to evaluate the accuracy and completeness of data.

1) Analysis of data possible to verify: Data on each item of CRF were classified into the following 3 groups and the possible verification rate, that is, the percentage of ( I ) + (II) to the total amount of data in CRF was calculated.

( I ) Data possible to do SDV [Data recorded in medical charts and possible to verify the original records (raw data)]

(II) Conditional data possible to do SDV (Data recorded in medical charts but impossible to verify the original records)

(III) Data impossible to do SDV

2 ) The details of (III) data impossible to do SDV were analyzed.

3 ) The details and frequency of inconsistency between CRF and source documents among data possible to do SDV $[($ I $)+($ II $)]$ were surveyed.

4 ) State of appearance of deviation was surveyed.

\section{Results}

(1) For SDV of 33 clinical trials (126 cases), the mean $97.5 \pm 4.0 \%$ (range : $85.8 \sim 100 \%$ ) of the average data amount $820.4 \pm 764.7$ (range : $36 \sim 3,773$ ) was possible to verify (Table 2 ).

(2) Data having a high verification rate $(95 \%$ or higher) were on accompanying symptom (99.9\%), observation period $(98.7 \%)$, laboratory examinations $(98.3 \%)$, items for observation (98.1\%), hospital/patient-related information $(96.9 \%)$, and the patient's background $(96.1 \%)$. On the other hand, the data with a 
Table 2 Percentage of Amount of SDV-possible Data to All Amount of Data in CRF as Verification Rate and Percentage of Amount of Inconsistent Data to That of SDV-possible Data as Inconsistency Rate

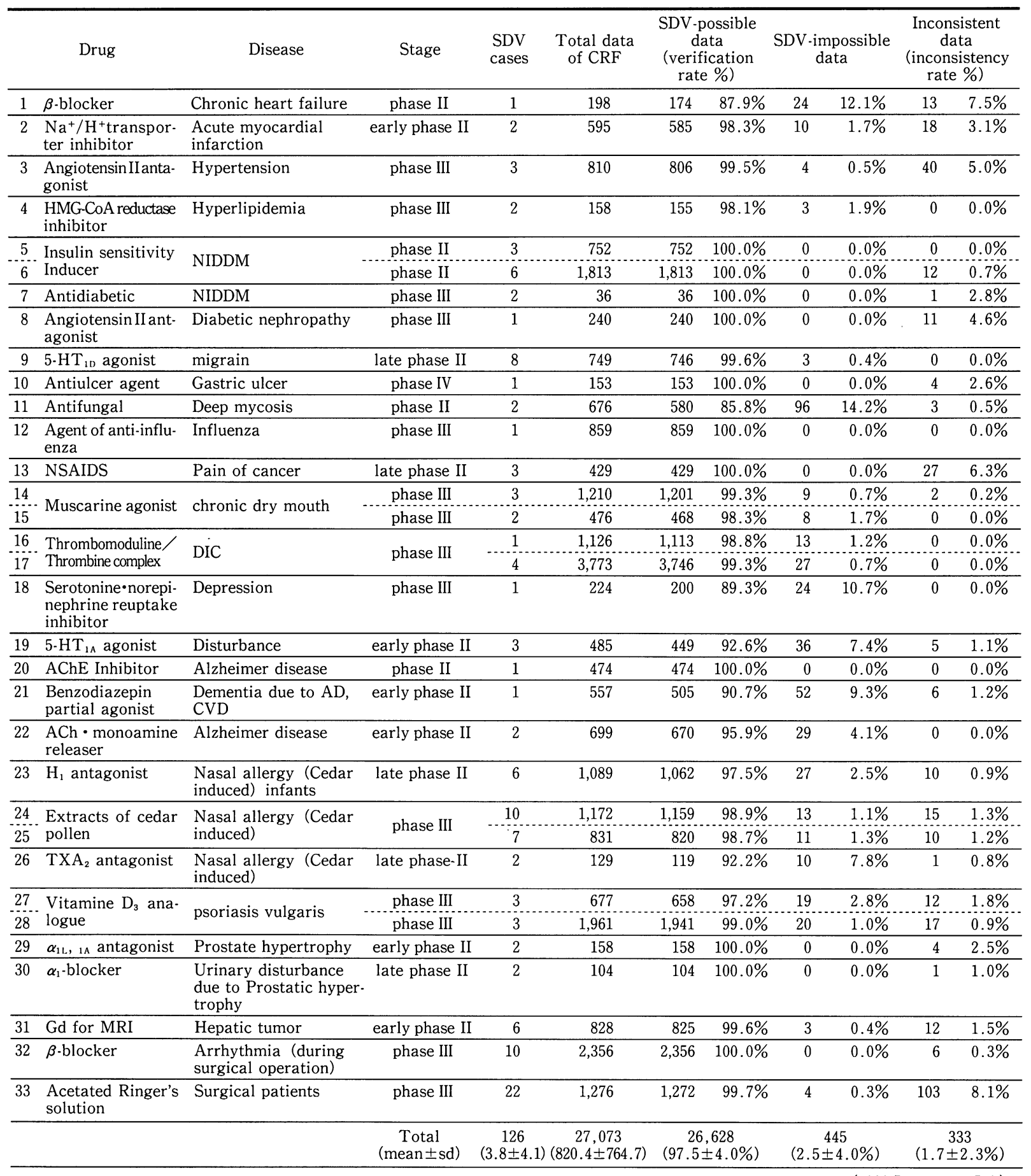


Table 3 Analysis of SDV-possible Data (Verification Rate)

in Relation to 10 Categories of Data

\begin{tabular}{lccc}
\hline \multicolumn{1}{c}{ Items of data } & $\begin{array}{c}\text { Number of } \\
\text { protocols }\end{array}$ & $\begin{array}{c}\text { Amount of SDV- } \\
\text { possible data }\end{array}$ & Verification rate \\
\hline $\begin{array}{l}\text { (1) Hospital/patient-related } \\
\text { information }\end{array}$ & 33 & $29.8 \pm 19.8(6 \sim 77)$ & $96.9 \pm 8.0 \% \quad(57.5 \sim 100 \%)$ \\
(2) Patient's background & 32 & $77.3 \pm 69.8(3 \sim 310)$ & $95.9 \pm 6.5 \%(76.5 \sim 100 \%)$ \\
(3) Observation period & 25 & $88.6 \pm 169.1(1 \sim 845)$ & $98.7 \pm 3.9 \%(81.6 \sim 100 \%)$ \\
(4) Items for observation & 32 & $256.7 \pm 362.3(3 \sim 1,774)$ & $98.1 \pm 6.7 \%(63.6 \sim 100 \%)$ \\
(5) Laboratory examinations & 32 & $240.7 \pm 233.0(2 \sim 1,070)$ & $98.3 \pm 4.8 \%(81.5 \sim 100 \%)$ \\
(6) Accompanying symptom & 17 & $100.4 \pm 216.9(1 \sim 894)$ & $99.9 \pm 0.5 \%(98.0 \sim 100 \%)$ \\
(7) Adverse drug reactions or & 29 & $30.7 \pm 32.6(1 \sim 138)$ & $90.0 \pm 23.0 \%(0 \sim 100 \%)$ \\
$\quad$ adverse events & 29 & $8.7 \pm 15.8(1 \sim 88)$ & $92.8 \pm 19.7 \% \quad(25.0 \sim 100 \%)$ \\
(8) Discontinuance & 24 & $81.0 \pm 128.7(2 \sim 435)$ & $82.9 \pm 0.2 \%(0 \sim 100 \%)$ \\
(9) Items for evaluations & 14 & $49.1 \pm 73.5(2 \sim 217)$ & $85.7 \pm 36.3 \% \quad(0 \sim 100 \%)$ \\
(10) Miscellaneous & 33 & $820.4 \pm 764.7(36 \sim 3,773)$ & $97.5 \pm 4.0 \% \quad(85.8 \sim 100 \%)$ \\
\hline$\quad$ Total (mean \pm SD) & & &
\end{tabular}

low verification rate was that on items for evaluations ( $82.9 \%$ ) followed by miscellaneous (85.7\%), adverse drug reactions or adverse events $(90.0 \%)$, and discontinuance $(92.8 \%)$

(Table 3).

(3) The reasons for impossibility to verify reported by the monitor could be classified into 5 categories as shown in Table 4.

A total of 386 of 445 data which were impossible to verify (86.7\%) fell into (C) ; the investigator entered the records directly into CRF without entering medical charts (no statement was made with regard to data entered to $\mathrm{CRF}$ as source data). A total of 26 data (5.8\%) fell into (D) ; data were impossible to verify because of the monitor's inappropriate interpretation of medical charts. A total of 21 data $(4.7 \%)$ fell into (B) ; nothing was entered to medical charts and no raw data such as laboratory test slips and medical charts of other department were prepared for SDV. No original data were missed (A). Miscellaneous causes were noted in 12 data (2.7\%) as follows (E) :

- Doctors did not check the medications the patients had received at previous hospitals.
- No abnormality on urine test, blood pressure and heart rate was seen in CRF but no statement of "no abnormality was found" was made in the medical charts. Because of that it was impossible to verify.

- Doctors did not understand how to enter the data in CRF because the CRF entry form was ambiguous. (A statement was made that the attached copy of the electrocardiogram was regarded as original data. However, there was confusion in the form where the time that the ECG was taken had to be entered separately.)

- The state of compliance to medication and concurrent treatment were unable to verify because the patient stopped visiting in the middle of the clinical trial.

(4) Among the total number of data ( I + II : 26,628 ) in which verification could be made, inconsistency was found between CRF and the source documents in 333 data. Thus, the inconsistency rate was $1.7 \pm 2.3 \%$ (range : $0 \sim 8.1 \%$ ) (Table 2). The details of inconsistency were roughly classified into 2 categories (Table 5 ) : data entered in CRF were not the same as those 
Table 4-1 Causes of Impossible Source Document Verification

A. Loss of source documents B. Insufficient preparation of source documents for SDV

C. The data direetly recorded in case report form, not in medical note (No identification the data recorded in CRF to be the source data)

D. Inappropriate reading of information in the medical note $\mathrm{E}$. Miscellaneous

(1) Hospital/patient-related information

\begin{tabular}{lcc}
\hline \multicolumn{1}{c}{ Item } & No. & $\begin{array}{c}\text { Cause of } \\
\text { impossible } \\
\text { SDV }\end{array}$ \\
\hline Data of writing CRF & 3 & C \\
Initial of name & 2 & D \\
Age & 2 & D \\
Date of confirming the check rist & 1 & C \\
Diagnosis & 1 & D \\
Eligibility criteria & 1 & C \\
Exclusion criteria & 9 & C \\
Name of doctor & 1 & D \\
Data of checking source & 2 & C \\
documents & 1 & C \\
Occupation & 2 & C \\
Code of patient & 1 & C \\
Other therapy & 6 & C \\
Date of final writing CRF & &
\end{tabular}

(2) Patient's background

\begin{tabular}{lrc}
\hline \multicolumn{1}{c}{ Item } & No. & $\begin{array}{c}\text { Cause of } \\
\text { impossible } \\
\text { SDV }\end{array}$ \\
\hline Body weight & 7 & C \\
Cigarette habit & 4 & C \\
Comment & 1 & D \\
Occurrence of disease & 1 & C \\
Former medicine & 1 & E \\
Previous theray & 1 & E \\
Coronary angiographical findings & 1 & B \\
Complication & 2 & C \\
Other treatments & 17 & B \\
Height of body & 5 & C \\
Psychiatric cause & 6 & C \\
Reasons of former drug changed & 4 & C \\
Diagnosis & 4 & C \\
Suspected date of fungal infection & 2 & C \\
Chief antigen & 2 & D \\
Dual antigen & 4 & D \\
Global severity & 10 & C \\
Incidence period & 4 & C \\
Presence of complication & 2 & C \\
Judgement of risk & 1 & C \\
Pregnancy or Lactation & 1 & C \\
\hline
\end{tabular}

(3) Observation period

\begin{tabular}{lcc}
\hline \multicolumn{1}{c}{ Item } & No. & $\begin{array}{c}\text { Cause of } \\
\text { impossible } \\
\text { SDV }\end{array}$ \\
\hline Concomitant therapy & 3 & D \\
Reasons for dose escalation & 4 & D \\
Concomitant drugs & 5 & C \\
Present illness & 2 & C \\
Allergic symptoms & 1 & C \\
Contrast medium for CT & 3 & B \\
\hline
\end{tabular}

(4) Items for observation

\begin{tabular}{lrc}
\hline \multicolumn{1}{c}{ Item } & No. & $\begin{array}{c}\text { Cause of } \\
\text { impossible } \\
\text { SDV }\end{array}$ \\
\hline Compliance & 3 & $\mathrm{C}$ \\
Reasons for concomitant therapy & 29 & $\mathrm{C}$ \\
Dose of concomitant drug & 2 & $\mathrm{C}$ \\
Compliance at 2nd week & 1 & $\mathrm{E}$ \\
Presence of concomitant therapy & 1 & $\mathrm{E}$ \\
Blood pressure & 1 & $\mathrm{C}$ \\
Heart rate & 1 & $\mathrm{C}$ \\
Reasons of concomitant drug & 1 & $\mathrm{C}$ \\
$\quad$ changed & 10 & $\mathrm{C}$ \\
Subjective symptom & 9 & $\mathrm{C}$ \\
Medical findings & 1 & $\mathrm{C}$ \\
Nasal hemorrhage & & \\
\hline
\end{tabular}

(5) Laboratory examinations

\begin{tabular}{lrc}
\hline \multicolumn{1}{c}{ Item } & No. & $\begin{array}{c}\text { Cause of } \\
\text { impossible } \\
\text { SDV }\end{array}$ \\
\hline Blood pressure & 8 & $\mathrm{C}$ \\
Presence of abnormality & 37 & $\mathrm{C}$ \\
Fraction of WBC & 5 & $\mathrm{D}$ \\
Judgement of abnormality & 6 & $\mathrm{E}$ \\
Comment & 4 & $\mathrm{C}$ \\
Causality & 12 & $\mathrm{C}$ \\
\hline \multicolumn{1}{c}{ Item } & & \\
6) Accompanying symptom & & \\
\hline & & Cause of \\
& No. & impossible \\
\hline Accompanying symptom & 1 & C \\
\hline
\end{tabular}


Table 4-1 (continued)

(7) Adverse drug reactions or adverse events

\begin{tabular}{lrc}
\hline \multicolumn{1}{c}{ Item } & No. & $\begin{array}{c}\text { Cause of } \\
\text { impossible } \\
\text { SDV }\end{array}$ \\
\hline Grade & 16 & $\mathrm{C}$ \\
Causality & 10 & $\mathrm{C}$ \\
Occurrence & 1 & $\mathrm{D}$ \\
Disappearance & 1 & $\mathrm{C}$ \\
Judgement & 2 & $\mathrm{C}$ \\
Classification of severity & 18 & $\mathrm{C}$ \\
Comment & 2 & $\mathrm{C}$ \\
Treatment and process of & 1 & $\mathrm{C}$ \\
$\quad$ abnormality & & $\mathrm{C}$ \\
Yes or No & 17 & $\mathrm{C}$ \\
Symptomatic therapy & 2 & $\mathrm{C}$ \\
Another drug & 1 & \\
\hline
\end{tabular}

(8) Discontinuance

\begin{tabular}{lcc}
\hline \multicolumn{1}{c}{ Item } & No. & $\begin{array}{c}\text { Cause of } \\
\text { impossible } \\
\text { SDV }\end{array}$ \\
\hline Follow up study & 1 & $\mathrm{C}$ \\
Yes or No & 1 & $\mathrm{C}$ \\
Date & 1 & $\mathrm{C}$ \\
Cause & 5 & $\mathrm{C}$ \\
Comment & 5 & $\mathrm{C}$ \\
\hline
\end{tabular}

Table 4-2 Frequency and Causes of SDV Impossibility

\begin{tabular}{lrl}
\hline \multicolumn{1}{c}{ Cause } & No. & \multicolumn{1}{c}{$(\%)$} \\
\hline A : Loss of source documents & 0 & $0.0 \%$ \\
B : Insufficient preparation of & 21 & $4.7 \%$ \\
$\quad \begin{array}{l}\text { source documents for SDV } \\
\text { The data directly recorded in } \\
\text { case report form, not in medi- } \\
\text { cal note (No identification } \\
\text { the data recorded in CRF to } \\
\text { be the source data) }\end{array}$ & 386 & $86.7 \%$ \\
D : Inappropriate reading of infor- \\
$\begin{array}{l}\text { mation in the medical note } \\
\text { E : Miscellaneous }\end{array}$ & 26 & $5.8 \%$ \\
\hline \multicolumn{1}{c}{ Total } & 12 & $2.7 \%$ \\
\hline
\end{tabular}

(9) Items for evaluations

\begin{tabular}{lrc}
\hline \multicolumn{1}{c}{ Item } & No. & $\begin{array}{c}\text { Cause of } \\
\text { impossible } \\
\text { SDV }\end{array}$ \\
\hline Severity & 3 & $\mathrm{C}$ \\
Global safety & 10 & $\mathrm{C}$ \\
Comment & 3 & $\mathrm{C}$ \\
Global evaluation & 4 & $\mathrm{C}$ \\
Time performing ECG & 2 & $\mathrm{E}$ \\
Global improvement & 29 & $\mathrm{C}$ \\
Effective \% of clinical finding & 3 & $\mathrm{C}$ \\
Micological effect & 3 & $\mathrm{C}$ \\
Serologically effectiveness & 3 & $\mathrm{C}$ \\
Image diagnostic effectiveness & 3 & $\mathrm{C}$ \\
Final effect & 2 & $\mathrm{C}$ \\
Impression of Pt. & 1 & $\mathrm{C}$ \\
Judgement of side effect & 11 & $\mathrm{C}$ \\
Presence of clinical or hemorrhagic & 15 & $\mathrm{C}$ \\
$\quad$ symptom & & $\mathrm{C}$ \\
Follow up study till pretreatment & 5 & $\mathrm{C}$ \\
\hline
\end{tabular}

(10) Miscellaneous

\begin{tabular}{ccc}
\hline Item & No. & $\begin{array}{c}\text { Cause of } \\
\text { impossible } \\
\text { SDV }\end{array}$ \\
\hline Summary and comment & 2 & C \\
\hline
\end{tabular}

recorded in source documents because of inaccurate entry in CRF ; incomplete data due to omission of entry. Others were miscalculation, misspelling, and contradiction between source data (Table 5). The type of inconsistency produced was characterized by the kind of data. Omission of entry in CRF was frequently found in the data of patient's background, items for observation, side effects and previous or concomitant medication were also frequently missed. On the other hand, inconsistency due to inaccurate entry to CRF was the most often found in laboratory tests: this is called transcription error which occurred when the investigator transferred the data from laboratory test slip to CRF. Details of inconsistency are shown in Table 5. 
Table 5 The Details of Inconsistency between Data Entered in CRF and Those in the Source Documents (1) Hospital/patient-related information

* shows a representative case of same kind of inconsistency observed

\begin{tabular}{lll}
\hline $\begin{array}{l}\text { Inaccurate entry } \\
\text { in CRF }\end{array}$ & $\begin{array}{l}\text { The date of informed } \\
\text { consent }\end{array}$ & $\begin{array}{l}\text { - The date entered in CRF is different from that in written } \\
\text { informed consent. [3/26/1999] in CRF, [4/1/1999] in written } \\
\text { informed consent }\end{array}$ \\
\cline { 2 - 4 } & $\begin{array}{l}\text { The registration num- } \\
\text { ber and age of subject }\end{array}$ & $\begin{array}{l}* \text { Age entered in CRF is different from that in medical chart. } \\
\text { [63 years old] in CRF, [67 years old] in medical chart }\end{array}$ \\
\hline $\begin{array}{l}\text { Omission of } \\
\text { entry }\end{array}$ & Drug therapy & $\begin{array}{l}\text { - No entry in CRF ; There are entries about } 3 \text { different drugs in } \\
\text { medical chart }\end{array}$ \\
\hline
\end{tabular}

(2) Patient's background

\begin{tabular}{|c|c|c|c|}
\hline \multirow{2}{*}{$\begin{array}{l}\text { Inconsistency } \\
\text { between original } \\
\text { documents }\end{array}$} & Time of onset & 1 & $\begin{array}{l}\text { - The description in CRF is the same as that in worksheet but } \\
\text { a different description is found in medical chart }\end{array}$ \\
\hline & Complication & 1 & $\begin{array}{l}\text { - The descriptions in CRF, medical chart and worksheet are } \\
\text { different from one another }\end{array}$ \\
\hline \multirow[t]{11}{*}{$\begin{array}{l}\text { Inaccurate entry } \\
\text { in CRF }\end{array}$} & Complication & 2 & $\begin{array}{l}\text { - [No complication] is entered in CRF but complicated diabetes } \\
\text { was ascertained from his (her) doctor } \\
\text { - [Gastritis, Insomnia] in CRF, [Constipation] in medical chart }\end{array}$ \\
\hline & Past history & 2 & $\begin{array}{l}\text { - [Old myocardial infarction] in CRF, [Myocardial infarction } \\
\text { in 1987] in medical chart } \\
\text { c [Hepatitis] in CRF, [Operation of cholelithiasis] in medical } \\
\text { chart }\end{array}$ \\
\hline & $\begin{array}{l}\text { History of allergic dis- } \\
\text { ease }\end{array}$ & 1 & - Described in CRF, [Nil] in medical chart \\
\hline & $\begin{array}{l}\text { Dose of concomitant } \\
\text { drug }\end{array}$ & 1 & $\begin{array}{l}\text { - Description about } 1 \text { drug in } \mathrm{CRF} \text { is different from that in } \\
\text { medical chart }\end{array}$ \\
\hline & $\begin{array}{l}\text { Presence or absence of } \\
\text { contraindicated drug to } \\
\text { take }\end{array}$ & 1 & - $[\mathrm{Nil}]$ in registration card, [Presence] in medical chart \\
\hline & $\begin{array}{l}\text { The date of starting } \\
\text { concurrent medication, } \\
\text { The date of myocardial } \\
\text { infarction onset, } \\
\text { Duration of pain, } \\
\text { Duration of sickning }\end{array}$ & 4 & - Description in CRF is different from that in medical chart \\
\hline & $\begin{array}{l}\text { Induced nose reaction, } \\
\text { Severity of blood pres- } \\
\text { sure }\end{array}$ & 2 & - Severity entered in CRF is different from that in medical chart \\
\hline & Diagnosis & 1 & $\begin{array}{l}\text { - [Congenital left aural fistula] in CRF, [Congenital aural fistula } \\
\text { (left)] in medical chart }\end{array}$ \\
\hline & $\begin{array}{l}\text { The date of obtaining } \\
\text { informed consent }\end{array}$ & 1 & - $[9 / 6 / 1999]$ in $\mathrm{CRF},[9 / 7 / 1999]$ in medical chart \\
\hline & $\begin{array}{l}\text { Medical chart number, } \\
\text { Initial }\end{array}$ & 2 & $\begin{array}{l}\text { - Number and initial entered in } \mathrm{CRF} \text { are different from those in } \\
\text { medical chart }\end{array}$ \\
\hline & Weight & 1 & $\begin{array}{l}\text { - Weight at the end of clinical trial is entered in CRF while } \\
\text { weight at the date of obtaining informed consent is entered in } \\
\text { medical chart }\end{array}$ \\
\hline
\end{tabular}


Table 5 (continued)

\begin{tabular}{|c|c|c|c|}
\hline Miswritten & $\begin{array}{l}\text { Complication, previous } \\
\text { disease }\end{array}$ & 2 & $\begin{array}{l}\text { - Wrong word of [cataract] } \\
\text { - Wrong word of [chronic pancreatitis] }\end{array}$ \\
\hline \multirow[t]{12}{*}{$\begin{array}{l}\text { Omission of } \\
\text { entry }\end{array}$} & $\begin{array}{l}\text { The name of concomi- } \\
\text { tant drug }\end{array}$ & 2 & $\begin{array}{l}* \text { [Nitrate agent tape] is entered in medical chart besides those } \\
\text { entered in CRF. }\end{array}$ \\
\hline & Past history & 10 & $\begin{array}{l}\text { * Additional previous diseases are entered in medical chart } \\
\text { besides that entered in CRF (Only [Colon polyp] is entered in } \\
\mathrm{CRF} \text { while [Chronic otitis media] etc. are entered in medical } \\
\text { chart besides colon polyp) } \\
\text { * [Nil] in CRF, Previous diseases such as [Herpes zoster] etc. } \\
\text { are entered in medical chart }\end{array}$ \\
\hline & Complication & 37 & $\begin{array}{l}\text { * No complication is entered in CRF but [Hypertension], } \\
\text { [Hyperuricemia], and [Borderline diabetes] are entered in } \\
\text { medical chart } \\
\text { * There are many cases having entries such as [Cancer }+] \text {, } \\
\text { [Allergy }+] \text {, and [Hypertension }+ \text { ] etc. } \\
\text { * Additional complications are entered in medical chart besides } \\
\text { that entered in CRF }\end{array}$ \\
\hline & $\begin{array}{l}\text { Daily dose of concomi- } \\
\text { tant drug, Duration of } \\
\text { concomitant drug use }\end{array}$ & 2 & $\begin{array}{l}\text { - Information on } 1 \text { drug is entered in CRF but information on } \\
\text { other drugs is entered in medical chart }\end{array}$ \\
\hline & $\begin{array}{l}\text { The name, route of ad- } \\
\text { ministration, and daily } \\
\text { dose of previous thera- } \\
\text { peutic agent, Site and } \\
\text { duration of previous } \\
\text { therapeutic agent used }\end{array}$ & 10 & - Information on 2 drugs is omitted in CRF \\
\hline & $\begin{array}{l}\text { Presence or absence of } \\
\text { severe ventricular arr- } \\
\text { hythmia }\end{array}$ & 1 & - [Absence] in CRF, [Presence] in medical chart \\
\hline & $\begin{array}{l}\text { The name of under- } \\
\text { lying disease }\end{array}$ & 1 & $\begin{array}{l}\text { - [Multiple myeloma] is marked in CRF but not selected } \\
\text { whether it is primary or recurrent condition. According to the } \\
\text { medical chart, it is recurrent one }\end{array}$ \\
\hline & Diagnosis & 1 & $\begin{array}{l}\text { - [Thyroid cancer] is entered in CRF, but [ } \mathrm{rt} \text { thyroid ca] is } \\
\text { entered in medical chart }\end{array}$ \\
\hline & The name of operation & 1 & $\begin{array}{l}\text { - Additional name of operation is entered in medical chart } \\
\text { besides that in CRF }\end{array}$ \\
\hline & $\begin{array}{l}\text { Family relationship of } \\
\text { proxy giving informed } \\
\text { consent }\end{array}$ & 1 & - It is entered in medical chart but no entry is made in CRF \\
\hline & Gender & 1 & - [Male] in CRF, [Male, F] in medical chart \\
\hline & $\begin{array}{l}\text { Family history of hy- } \\
\text { pertension, maternal }\end{array}$ & 1 & - [Nil] in CRF, [Unknown] in medical chart \\
\hline Mis-calculation & Duration of anesthesia & 1 & $\begin{array}{l}\text { - Miscalculated duration of anesthesia derived from starting and } \\
\text { terminating time of anesthesia }\end{array}$ \\
\hline
\end{tabular}


Table 5 (continued)

(3) Observation period

\begin{tabular}{|c|c|c|c|}
\hline \multirow[t]{5}{*}{$\begin{array}{l}\text { Inaccurate entry } \\
\text { in } \mathrm{CRF}\end{array}$} & $\begin{array}{l}\text { Duration of concomi- } \\
\text { tant drug administra- } \\
\text { tion. The quantity of } \\
\text { concomitant drug con- } \\
\text { sumed The name of } \\
\text { concomitant drug. The } \\
\text { date of evaluation. } \\
\text { Laboratory tests im- } \\
\text { plemented during } \\
\text { observation period }\end{array}$ & 13 & - Information in CRF is different from that in medical chart \\
\hline & $\begin{array}{l}\text { Frequency of concomi- } \\
\text { tant drug administra- } \\
\text { tion }\end{array}$ & 1 & $\begin{array}{l}\text { - A tranquilizer [3 times/day] is entered in CRF but [2 times/ } \\
\text { day] in medical chart }\end{array}$ \\
\hline & $\begin{array}{l}\text { The time of examina- } \\
\text { tion }\end{array}$ & 1 & - $[9: 09]$ in $\mathrm{CRF},[8: 55]$ in medical chart \\
\hline & $\begin{array}{l}\text { Observation period } 4 \\
\text { weeks }\end{array}$ & 1 & - $[\sim$ May 8 th $]$ in $\mathrm{CRF},[\sim$ May 10 th $]$ in medical chart \\
\hline & $\begin{array}{l}\text { Treatment period } 4 \\
\text { weeks: The date of the } \\
\text { III drug evaluation }\end{array}$ & 1 & - [July 19th ] in CRF, [July 6th ] in medical chart \\
\hline \multirow[t]{3}{*}{$\begin{array}{l}\text { Omission of } \\
\text { entry }\end{array}$} & $\begin{array}{l}\text { The name of concomi- } \\
\text { tant drug }\end{array}$ & 7 & $\begin{array}{l}\text { - There is a drug entered in medical chart without being entered } \\
\text { in CRF }\end{array}$ \\
\hline & $\begin{array}{l}\text { Duration of concomi- } \\
\text { tant drug used }\end{array}$ & 1 & \\
\hline & $\begin{array}{l}\text { The purpose of con- } \\
\text { comitant drug use. The } \\
\text { quantity of concomi- } \\
\text { tant drug consumed }\end{array}$ & 9 & - There is entry in medical chart but no entry in CRF \\
\hline $\begin{array}{l}\text { Inconsistency } \\
\text { between original } \\
\text { documents }\end{array}$ & Prescribed tablet & 2 & $\begin{array}{l}\text { - Description in medical chart is consistent with that in CRF but } \\
\text { inconsistent with the description in investigational drug control } \\
\text { table }\end{array}$ \\
\hline
\end{tabular}

(4) Items for observation

\begin{tabular}{|c|c|c|c|}
\hline \multirow[t]{4}{*}{$\begin{array}{l}\text { Inaccurate entry } \\
\text { in } \mathrm{CRF}\end{array}$} & $\begin{array}{l}\text { Cumulative amount of } \\
\text { bleeding }\end{array}$ & 5 & $\begin{array}{l}\text { - Amount of bleeding in CRF is different from that in medical } \\
\text { chart }\end{array}$ \\
\hline & $\begin{array}{l}\text { TIMI classification, } \\
\text { The time of starting } \\
\text { reperfusion }\end{array}$ & 4 & - Information in $\mathrm{CRF}$ is different from that in medical chart \\
\hline & $\begin{array}{l}\text { The date of blood pres- } \\
\text { sure and pulse measure- } \\
\text { ment }\end{array}$ & 1 & $\begin{array}{l}\text { - }[4 / 26 / 2000] \text { in } C R F \text { and worksheet, }[5 / 3 / 2000] \text { in medical chart, } \\
\text { Collection of the date in CRF }\end{array}$ \\
\hline & $\begin{array}{l}\text { Heart rate, blood pres- } \\
\text { sure }\end{array}$ & 2 & - Incorrect value in $\mathrm{CRF}$ \\
\hline
\end{tabular}


Table 5 (continued)

\begin{tabular}{|c|c|c|c|}
\hline \multirow[t]{12}{*}{$\begin{array}{l}\text { Inaccurate entry } \\
\text { in } \mathrm{CRF}\end{array}$} & $\begin{array}{l}\text { Judgement of hypoten- } \\
\text { sive effect. Basal blood } \\
\text { pressure-blood pressure } \\
\text { at the time of judg- } \\
\text { ment. Basal blood pres- } \\
\text { sure. Confirmation of } \\
\text { dose escalation criteria }\end{array}$ & 16 & - The values in CRF are different from those in medical chart \\
\hline & Concomitant drug & 4 & $\begin{array}{l}\text { - Description in } \mathrm{CRF} \text { is different from that in medical chart } \\
\text { * The date of drip infusion in } \mathrm{CRF} \text { is different from that in } \\
\text { medical chart }\end{array}$ \\
\hline & $\begin{array}{l}\text { Investigational drug, } \\
\text { Duration of investiga- } \\
\text { tional drug prescription }\end{array}$ & 3 & $\begin{array}{l}\text { * [The II drug] in CRF, [The I drug] in medical chart } \\
\text { - The duration is inconsistent between CRF and medical chart }\end{array}$ \\
\hline & Cumulative dosage & 1 & - $[1,310 \mathrm{ml}]$ in $\mathrm{CRF},[1,210 \mathrm{ml}]$ in medical chart \\
\hline & Induction agent & 1 & - $[7 \mathrm{ml}]$ in $\mathrm{CRF},[5 \mathrm{ml}]$ in medical chart \\
\hline & Duration of suffering & 1 & - $[\sim 8$ weeks $]$ in $\mathrm{CRF},[\sim 1$ month $]$ in medical chart \\
\hline & Weight & 1 & $\begin{array}{l}\text { - Corrected weight in } \mathrm{CRF} \text { is different from the weight in } \\
\text { original data }\end{array}$ \\
\hline & Signal intensity & 2 & $\begin{array}{l}\text { - The values of background noise and kidney }(40 \sim 120 \text { minutes } \\
\text { after administration) are inconsistent between } \mathrm{CRF} \text { and medical } \\
\text { chart }\end{array}$ \\
\hline & Concomitant symptom & 1 & $\begin{array}{l}\text { - No entry in CRF [Stopped injection due to fever } 37.3^{\circ} \mathrm{C} \text { ] is } \\
\text { entered in medical chart }\end{array}$ \\
\hline & $\begin{array}{l}\text { Judgement of MMSE } \\
\text { correct answers }\end{array}$ & 2 & $\begin{array}{l}\text { - The date of implementation in CRF is incorrect } \\
\text { - Correct answer is mistakenly interpreted as incorrect }\end{array}$ \\
\hline & $\begin{array}{l}\text { Secretory rate (before } \\
\text { administration) }\end{array}$ & 2 & $\begin{array}{l}\cdot[+] \text { in } \mathrm{CRF},[3+] \text { in original document (diary) } \\
\cdot[-] \text { in } \mathrm{CRF},[2+] \text { in original document (diary) }\end{array}$ \\
\hline & $\begin{array}{l}\text { Secretory rate ( } 2 \text { weeks } \\
\text { after administration) }\end{array}$ & 1 & $\cdot[+]$ in $\mathrm{CRF},[2+]$ in original document (diary) \\
\hline \multirow[t]{4}{*}{$\begin{array}{l}\text { Omission of } \\
\text { entry }\end{array}$} & $\begin{array}{l}\text { Concomitant drug (the } \\
\text { name of drug, dosage, } \\
\text { time of administration, } \\
\text { unit, duration of pre- } \\
\text { scription, purpose of } \\
\text { treatment) }\end{array}$ & 21 & $\begin{array}{l}\text { * Slash mark in CRF, [Gastric agent] in medical record } \\
\text { - Part of concomitant drugs entered in medical chart are not } \\
\text { entered in CRF } \\
* \text { Only [Bosmin } 4 \mathrm{cc}, 9: 30 \text { ] is entered in CRF but [1\% Xylocaine } \\
4 \mathrm{ml}, 9: 34] \text { is entered in medical chart besides Bosmin } \\
*[\mathrm{Ni1}] \text { is marked in CRF but [Bosmin physiological saline } \\
\text { solution, 9:00] is entered in medical chart }\end{array}$ \\
\hline & $\begin{array}{l}\text { Change of concomitant } \\
\text { drug (the name of drug, } \\
\text { dosage regimen, dose, } \\
\text { duration of administra- } \\
\text { tion, reason) }\end{array}$ & 8 & - It is entered in medical chart but no entry is made in CRF. \\
\hline & The name of operation & 1 & $\begin{array}{l}\text { - [Chronic otitis media] in CRF, [Tympanoplasty, Left } \\
\text { antrotomy] in medical chart }\end{array}$ \\
\hline & $\begin{array}{l}\text { Electrocardiogram fin- } \\
\text { dings }\end{array}$ & 1 & - No entry in CRF, [sinus bradycardia] in medical record \\
\hline
\end{tabular}


Table 5 (continued)

\begin{tabular}{|c|c|c|c|}
\hline \multirow[t]{2}{*}{$\begin{array}{l}\text { Omission of } \\
\text { entry }\end{array}$} & $\begin{array}{l}\text { Subjective symptom } \\
\text { and objective symptom }\end{array}$ & 4 & $\begin{array}{l}*[\mathrm{Nil}] \text { in } \mathrm{CRF},[\text { Feeling of headache }] \text { in medical record } \\
*[0 \text { (nil) }] \text { in } \mathrm{CRF},[1 \text { (week) }] \text { in medical chart } \\
*[\mathrm{Nil}] \text { in } \mathrm{CRF},[\text { Presence }] \text { in medical chart }\end{array}$ \\
\hline & $\begin{array}{l}\text { Character of nasal dis- } \\
\text { charge }\end{array}$ & 1 & $\begin{array}{l}\text { - }[\mathrm{Nil}] \text { is marked in CRF, but [watery] is entered in original } \\
\text { document (diary) }\end{array}$ \\
\hline
\end{tabular}

(5) Laboratory examinations

\begin{tabular}{|c|c|c|c|}
\hline \multirow{6}{*}{$\begin{array}{l}\text { Inaccurate entry } \\
\text { in CRF (transcr- } \\
\text { iption error) }\end{array}$} & $\begin{array}{l}\text { Laboratory test values } \\
\text { (blood) }\end{array}$ & 16 & - Incorrect posting from test slips to CRF \\
\hline & Urine test & 7 & $\begin{array}{l}\text { * Qualitative protein (after administration) }[-] \text { in CRF, }[+] \\
\text { in medical chart } \\
\text { * Incorrect posting of urobilinogen value } \\
\text { * Urinary sediment, erythrocyte }[-] \text { in CRF, }[+] \text { in medical } \\
\text { chart }\end{array}$ \\
\hline & $\begin{array}{l}\text { Judgment of normal or } \\
\text { abnormal }\end{array}$ & 16 & $\begin{array}{l}\text { * Normal hematocrit is entered as abnormal } \\
\text { * Incorrect judgement of normal or abnormal in CRF } \\
\text { * Total cholesterol level [abnormal] in CRF, [normal] in } \\
\text { medical chart } \\
\text { * Erythrocyte count and hemoglobin level on the following day } \\
\text { of withdrawal are inconsistent between CRF and medical chart }\end{array}$ \\
\hline & $\begin{array}{l}\text { The date of follow-up } \\
\text { examination }\end{array}$ & 2 & $\begin{array}{l}* \mathrm{~K}, \mathrm{Cl} \text { data on } 12 / 16 \text { in } \mathrm{CRF} \text { are found to be data on } 12 / \\
3 \text { (incorrect posting) }\end{array}$ \\
\hline & Allergy test & 18 & $\begin{array}{l}\text { * Because the unit of specific } \operatorname{IgE} \text { antibody measurement was } \\
\text { changed due to the change of measurement method, the unit } \\
\text { originally entered in CRF is corrected } \\
\text { * Value of specific IgE antibody (cedar) is inconsistent between } \\
\text { CRF and medical chart } \\
\text { * Result of provocation test, lymphocyte count and basophil } \\
\text { count are inconsistent between CRF and medical chart. (incor- } \\
\text { rect posting) }\end{array}$ \\
\hline & Numerical value & 1 & - Numerical values of $\mathrm{ACTH}$ and cortisol are inversely entered \\
\hline \multirow[t]{3}{*}{$\begin{array}{l}\text { Omission of } \\
\text { entry }\end{array}$} & $\begin{array}{l}\text { Follow-up values, fol- } \\
\text { low-up examination, IP } \\
\text { data }\end{array}$ & 4 & $\begin{array}{l}\text { - Nothing is entered in } \mathrm{CRF} \text { although they are entered in } \\
\text { medical chart }\end{array}$ \\
\hline & $\begin{array}{l}\text { Implementation or } \\
\text { non-implementation of } \\
\text { test }\end{array}$ & 2 & $\begin{array}{l}\text { - Implementation or non-implementation of blood collection and } \\
\text { urine collection for centralized measurement is entered in } \\
\text { medical chart but nothing is entered in CRF }\end{array}$ \\
\hline & Unit of urine test & 3 & * No entry on urobilinogen in CRF \\
\hline
\end{tabular}

(6) Accompanying symptom

\begin{tabular}{|c|c|c|c|}
\hline \multirow[t]{3}{*}{$\begin{array}{l}\text { Inaccurate entry } \\
\text { in } \mathrm{CRF}\end{array}$} & $\begin{array}{l}\text { Administration and } \\
\text { dosage of concomitant } \\
\text { drug }\end{array}$ & 1 & - Information in $\mathrm{CRF}$ is different from that in medical record \\
\hline & The date of onset & 1 & $\begin{array}{l}\text { - The date of onset of gustatory abnormality entered in CRF is } \\
\text { incorrect }\end{array}$ \\
\hline & Medical record & 1 & $\begin{array}{l}\text { - [Cataract] and [anemia] are entered in medical chart besides } \\
\text { information entered in CRF }\end{array}$ \\
\hline
\end{tabular}


Table 5 (continued)

(7) Adverse drug reactions or adverse events

\begin{tabular}{|c|c|c|c|}
\hline \multirow[t]{2}{*}{$\begin{array}{l}\text { Inaccurate entry } \\
\text { in CRF }\end{array}$} & $\begin{array}{l}\text { The date and time of } \\
\text { onset }\end{array}$ & 1 & - [7/22/1999] in CRF, [7/21/1999] in medical chart \\
\hline & $\begin{array}{l}\text { Adverse event/abnor- } \\
\text { mal fluctuation of adv- } \\
\text { erse event }\end{array}$ & 1 & - [1 week] in CRF, [-48 days] in medical chart \\
\hline \multirow{3}{*}{$\begin{array}{l}\text { Omission of } \\
\text { entry }\end{array}$} & Presence or absence & 4 & - [Absence] in CRF, [Presence] in medical chart \\
\hline & Drug used & 20 & $\begin{array}{l}* \text { Doctor concluded that bleeding during operation caused ane- } \\
\text { mia and no entry of side effect was made in CRF }\end{array}$ \\
\hline & $\begin{array}{l}\text { Symptom, severity, the } \\
\text { date of onset, treat- } \\
\text { ment/course, comment } \\
\text { on treatment/course, } \\
\text { the date of conclusion, } \\
\text { outcome, cause and } \\
\text { effect }\end{array}$ & 16 & $\begin{array}{l}* \text { No entry is made in CRF. Entries such as fracture, common } \\
\text { cold, anemia, moderate, mild, } 8 / 9 / 1999 \text { etc. and continue, fixa- } \\
\text { tion with plaster done by other hospital, } 9 / 8 \text { etc., disappeared, no } \\
\text { relationship etc. are made in medical chart }\end{array}$ \\
\hline
\end{tabular}

(8) Discontinuance (nil)

(9) Items for evaluation

\begin{tabular}{llll}
\hline $\begin{array}{l}\text { Inaccurate entry } \\
\text { in CRF }\end{array}$ & $\begin{array}{l}\text { Presence or absence of } \\
\text { chest pain }\end{array}$ & 1 & $\cdot$ [Unknown] in worksheet, [Nil] in medical chart \\
\cline { 2 - 4 } & Hypotensive effect & 1 & $\cdot[2$ (slightly dropped) $]$ in CRF, [1 (dropped) ] in medical chart \\
\hline
\end{tabular}

(10) Miscellaneous

\begin{tabular}{lll}
\hline $\begin{array}{l}\text { Inaccurate entry } \\
\text { in } \mathrm{CRF}\end{array}$ & $\begin{array}{r}\text { Imaging time } \\
\text { T } 1 \text { enhanced image to starting imaging is [40 min.] in CRF and } \\
\end{array}$ \\
\hline
\end{tabular}

Table 6 Details of Deviation

* shows a representative case of same kind of deviation observed

\begin{tabular}{|c|c|c|}
\hline Matters for deviation & No. & Details of deviation \\
\hline $\begin{array}{l}\text { Visiting at unappro- } \\
\text { priate day }\end{array}$ & 2 & $\begin{array}{l}* \text { Patient visited } 4 \text { days after taking drug even though the rule stated that the } \\
\text { patient should visit between } 8 \text { and } 15 \text { days after taking drug }\end{array}$ \\
\hline \multirow{6}{*}{$\begin{array}{l}\text { Examination not } \\
\text { performed }\end{array}$} & 4 & - Blood pressure measurement before starting administration \\
\hline & 2 & - Electrocardiogram after administration \\
\hline & 2 & - Blood, biochemical, and urine test after administration \\
\hline & 1 & - Forgetting measurement of residual urine at 4 weeks \\
\hline & 2 & - Examination for allergic condition \\
\hline & 5 & $\begin{array}{l}\text { * Mistake of ordering test to central laboratory (Mistake of order slip marking) } \\
\text { * Impossible to measure due to blood coagulation }\end{array}$ \\
\hline
\end{tabular}


Table 6 (countinued)

\begin{tabular}{|c|c|c|}
\hline Matters for deviation & No. & Details of deviation \\
\hline \multirow[t]{5}{*}{$\begin{array}{l}\text { Examination not } \\
\text { performed }\end{array}$} & 16 & $\begin{array}{l}* \text { Hematological and biochemical test at beginning of observation or right before } \\
\text { administration }\end{array}$ \\
\hline & 1 & - $\mathrm{A} / \mathrm{G}$ before and at the end of administration \\
\hline & 3 & - Urine test before and after administration \\
\hline & 1 & - Items required to measure after visit 8 \\
\hline & 10 & - Leukocyte fraction \\
\hline \multirow[t]{2}{*}{$\begin{array}{l}\text { Date of examination } \\
\text { delayed }\end{array}$} & 1 & $\begin{array}{l}\text { - Although protocol requires the last examination should be performed within } 2 \sim 5 \\
\text { weeks after admission, actual examination was performed } 6 \text { weeks after admission }\end{array}$ \\
\hline & 1 & $\begin{array}{l}\text { - Urine test before administration was actually performed } 7 \text { days after starting } \\
\text { administration }\end{array}$ \\
\hline $\begin{array}{l}\text { Frequency of the } \\
\text { measurement }\end{array}$ & 1 & $\begin{array}{l}\text { - Although } 3 \text { blood pressure measurements are required, only } 1 \text { or } 2 \text { measurements } \\
\text { were performed }\end{array}$ \\
\hline Missing evaluation & 1 & - Forgetting DAD measurement \\
\hline Prescribed period & 1 & - $(4 \mathrm{~W} \rightarrow 7 \mathrm{~W})$, the number of tablets \\
\hline Delayed dosing & 1 & $\begin{array}{l}\text { - Although protocol prescribes the } 3 \text { rd administration of investigational drug must } \\
\text { be done } 16 \text { hours after the first administration, actual administration was done } 16 \\
\text { hours } 10 \text { minutes after the first administration due to the error in implementation }\end{array}$ \\
\hline $\begin{array}{l}\text { Incorrect dosing int- } \\
\text { erval }\end{array}$ & 3 & $\begin{array}{l}\text { * Investigational drug was taken later than } 12 \text { weeks from the stipulated date of } \\
\text { prescription. The drug must be taken within } 12 \text { weeks from the stipulated date of } \\
\text { prescription }\end{array}$ \\
\hline Incorrect dose & 1 & - Incorrect dosage regimen \\
\hline $\begin{array}{l}\text { Contra concomitant } \\
\text { drug employed }\end{array}$ & 3 & $\begin{array}{l}\text { * It was found that patient was taking drug contraindicated within } 4 \text { weeks from } \\
\text { starting control observation period }\end{array}$ \\
\hline $\begin{array}{l}\text { Incorrect escalation } \\
\text { of dose }\end{array}$ & 1 & $\begin{array}{l}\text { - Although escalation of investigational drug dose is not allowed later than } 8 \\
\text { weeks, the dose was escalated at } 10 \text { weeks }\end{array}$ \\
\hline $\begin{array}{l}\text { Out of exclusion } \\
\text { criteria }\end{array}$ & 1 & - Patient with history of drug allergy was enrolled \\
\hline \multirow{2}{*}{$\begin{array}{l}\text { Out of incursion cri- } \\
\text { teria }\end{array}$} & 1 & - Contraindicated site was selected \\
\hline & 1 & $\begin{array}{l}\text { - Conformed to the criteria after retesting } \\
\rightarrow \text { shifted to treatment period }\end{array}$ \\
\hline \multirow[t]{2}{*}{$\begin{array}{l}\text { Incorrect informed } \\
\text { consent }\end{array}$} & 1 & $\begin{array}{l}\text { - Because there was no informed consent of Nippon Medical School available, a } \\
\text { form, copy of the informed consent text in the plan for implementation of clinical } \\
\text { trial was used }\end{array}$ \\
\hline & 1 & - Directly obtained informed consent \\
\hline Total & 68 & \\
\hline
\end{tabular}

(5) In 126 cases of 33 clinical trials 68 deviations were found. The majority of the deviations were because laboratory tests had not been carried out $(47,69.1 \%)$. There were
$4(5.9 \%)$ timing and time of medication related deviations, and in $2(2.9 \%)$ the date of the laboratory test relayed deviations (Table 6). Serious deviations observed were out of exclu- 
sion/inclusion criteria, out of the timing of informed consent, and omission of evaluation.

\section{Discussion}

Nippon Medical School Hospital where this survey was carried out is a general hospital with 1,164 beds. The number of clinical trials conducted in this hospital was 189 in 1995, 178 in 1996, 111 in 1997, 82 in 1998, 53 in 1999, and 49 in 2000 as IRB (Institutional Review Board for Drugs) cases. This number of cases may represent the average level of trials at university hospitals in Japan. Therefore, we carried out this survey to determine the details of clinical trials in this hospital, intending that the state of clinical trials in this hospital may reflect the actual state of clinical trials in other university hospitals.

SDV is a basic requirement in ICH-GCP ; it is carried out by monitors. However, collecting the clinical data and completing CRF to sponsor are performed by the investigator team at the site. In order to conduct self evaluation of clinical trial data, 3 kinds of quality measurements : the verification rate; the inconsistency rate of clinical trials and occurrence state of deviation were surveyed using SDV carried out in Nippon Medical School Hospital. The former 2 items evaluate the clinical trial data itself, and the latter can be a quality scale to evaluate the attitude toward the clinical trial.

\section{Evaluation of verification rate}

The verification rate in this survey carried out 2 years after the full enforcement of the new GCP was $97.5 \pm 4.0 \%$ which was $11 \%$ higher than $86.4 \pm 12.9 \%$ of the verification rate shown in the survey carried out from October to December in 1997. Two years have past since the new GCP went into effect. During that period, the awareness of the new GCP in medical institutions has been greatly enhanced and many institutions have become used to conducting SDV to maintain the quality of clinical trial data. The rise in the verification rate seen during the past 2 years likely reflects an increase in the skill for clinical trials at medical institutions. Conversely, if we know the verification rate of a clinical trial in a medical institution, we can judge the level of clinical trials conducted at that medical institution. The possibility to verify the CRF data means that at least the medical institution keeps the original data that is the basis of CRF.

The verification rate showed differences depending on the kind of data in this survey (Table 3). Data items for evaluation gave the lowest verification rate, followed by miscellaneous and adverse drug reactions or adverse events. When analyzing the reason for impossibility of verification, a direct entry was made in the CRF without entering original data in medical charts in the vast majority of such cases. Because comments for evaluation items, adverse drug reactions or adverse events etc. were usually entered directly in $\mathrm{CRF}$, the verification rate for these data was low (Table 4). In addition, in some cases, for example source data on items for a patient's background were impossible to verify from medical charts because information from other medical institutions was not usually posted. In contrast, monitors could not correctly read the medical records such as medical charts and thus in some cases they could not find the source data, which led to failure of verification. In any case, the key to reliability of a clinical trial is the presence of source data and the verifiability of that data. Therefore, the verification rate is a measurement of quality to confirm clinical trials conducted in a medical institution.

Analysis of the results of this survey suggest- 
ed that there are 2 approaches to improve the verification rate. If the purpose is to improve only the verification rate, it can be achieved by stating in the protocol that data entered directly in the CRF are identified as source data as shown in ICH-GCP (6-4-9). The idea to regard $\mathrm{CRF}$ as a source document is welcomed by the clinical trial sponsor because the verification process becomes simple while doctors also welcome this idea without requiring entry in both CRF and medical charts because they can save time. This approach, however, has a big problem that there is little information recorded in the medical charts on patients who are enrolled the clinical trial.

Another approach is that investigational physicians fulfill their data management duty by writing on the medical charts. There is a responsibility for all physicians investigating or treating patients to document any relevant findings and changes to current therapy. The records on what they have done and what they found including the evaluation of the results must be kept together with the information of any other treatments the patient has received. Consequently, the official medical records must include core information on the diseases and treatments for all the patients. It is important that the information on the patient's enrollment in clinical trial is recorded as a part of the standard hospital documentation for patients. Schuyl and Engel ${ }^{3)}$ stated that it is necessary to record the fact that the patient is in a clinical trial, the dates of visits, all severe adverse events, any concomitant diseases, confirmation of diseases under treatment, and main items for evaluation of the effectiveness on the medical charts. We do not agree with the preparation of the medical chart for the clinical trial separately. We maintain the belief that the medical chart should be prepared including all the infor- mation as an official patient document. Most of the information concerning the clinical trial can be included in the ordinary medical chart by using the worksheet. Preparing a separate medical chart for clinical trial makes the procedure more complicated. Ideally, 1 medical chart for 1 patient should be prepared. When the complete details are recorded accurately, the verification rate should be improved naturally.

\section{Evaluation of inconsistency rate}

Among the data ( I + II) in which verification between source documents and CRF data was possible, $1.7 \pm 2.3 \%$ of the data showed inconsistency. There has been no report of the basis in Japan to judge whether this result is good or bad. In the English language literature, Schuyl and Engel ${ }^{3)}$ suggest that the acceptable inconsistency rate should be less than $1 \%$ and it should be close to 0 for particularly important data. According to the survey ${ }^{4}$ on the occurrence rate of error when entering $\mathrm{CRF}$, errors caused by incomplete entry were found in $0.5 \%$ of data. "Critical data" are the key data for the purpose of the clinical trial and they must be accurate. For example, they are "primary endpoint", "serious adverse events" etc. In the present survey on important data, the following results were obtained:

(1) There was little inconsistency in the items for evaluation.

(2) Some discrepancies were found in the evaluation of side effects between doctors and monitors who conduct SDV. Although the doctor enters the possible side effects in the medical chart, they sometimes do not enter them in CRF. The typical example of such case was found in the drug administered during trials in surgical operation. In that case, the monitor thought that the postoperative decrease in hemoglobin level should be entered in CRF as 
an adverse event while the doctor did not consider it as a side effect because he diagnosed it was due to anemia caused by hemorrhage during operation.

On the other hand, "non-critical data" should also be accurate but most of the data such as laboratory examination values have less influence on the result of the clinical trial. Numerous inconsistencies of such data were found in this survey data due to incorrect transcription.

During a clinical trial, a large amount of data is generated. To maintain the accuracy of the data, the most important thing is to eliminate incorrect data ${ }^{5}$. For that, the possible sources of incorrect data must be identified, taking carelessness and even corrupt practice into consideration. Intentionally produced false data and faulty data produced by the wrong procedure must be distinguished from a simple minor error such as a transcription error. Since data are generated and they are entered in CRF in the medical institution, the prevention and correction of inconsistency among data should be done in the medical institution. In this survey, it was virtually impossible to identify whether or not the wrong data were produced intentionally. Prevention of errors is preferable to intervention. The best means to prevent inconsistency is to establish a system within the medical institution to confirm whether all the source documents are identified and kept and to ensure that all the relevant data are entered in $\mathrm{CRF}$ with accurate and complete form. If the clinical research coordinator (CRC) plays a role in such a data keeping system, it is possible to prevent the production of wrong data as described above.

There were some cases where data required in the protocol could not be entered because of faulty CRF design. For example, many doctors made an incomplete entry in items where the proper blank had to be selected and checked and then the comments had to be entered. There were also many mistakes found in the form where the calculated amount of transfusion during operation had to be entered. The design of CRF must be as simple as possible.

\section{Occurrence state of deviation}

Deviation occurred in the following process $\left.{ }^{6}\right)$ of the clinical trial.

(1) Clinical trial must be conducted in accordance with GCP.

(2) Data obtained from clinical trial must be conformed to the protocol.

(3) CRF data must be obtained from the clinical trial.

In this survey, the over whelming majority of deviations were cases where the examinations were not performed yet, which falls into the above category (3). Many were due to the investigator's carelessness and they might not have occurred if CRC had made proper scheduling. Out of exclusion and inclusion criteria, omission of evaluation falling into the category (2) and violation of timing for informed consent falling into the category (1) are considered as serious deviations.

Important thing is to consider that some occurrence of deviation is inevitable and to take proper measures regarding the deviations that have already occurred. In ICH-GCP (1996), the description about measures taken for deviations made is as follows: "4 4.3 The investigator, or person designated by the investigator should document and explain any deviation from the approved protocol." When the chief investigator fails to take proper action regarding deviation, he (she) violates GCP. In this survey, all the deviations were documented.

In multiple step data collection as shown in Fig. 1, several measurements of quality of data 
that are associated with each step can be set. Clarke $^{5)}$ listed two measurements of quality, were accuracy of raw data and complete information processing from CRF to database in the viewpoint of clinical data management. In view of the verification rate, inconsistency rate and occurrence state of deviation found in this survey, it was realized that the medical institution could check the quality of clinical trial data. On the whole, the data error observed in this survey was considered within the acceptable range. If this result represents the level of clinical trials implemented in Japanese university hospitals, it can be concluded that the current level of clinical trials in Japan at 3 years after enforcement of new GCP is an appropriate level. This survey was carried out based on the report of SDV results implemented by the monitor and inspection implemented by IRB office. It is expected that standardized collection and validation of clinical trial data will be carried out by the internal monitoring of the medical institution under the clinical trial system with well-trained CRC in the future.

\section{Conclusion}

(1) Verification rate, inconsistency rate and occurrence state of deviation were surveyed for the result of SDV from 33 clinical trials (126 cases) carried out in Nippon Medical School Hospital in order to evaluate the accuracy and completeness of the data collected in a medical institution.

(2) In the SDV of 126 cases, the verification rate was $97.5 \pm 4.0 \%$ (range : $85.8 \sim 100 \%$ ). The data with the lowest verification rate was on items for "evaluation (82.9\%)".

(3) Among 26,628 data for which verification was possible, inconsistency was found between $\mathrm{CRF}$ and the source documents in 333 data $[1.7 \pm 2.3 \%$ (range : $0 \sim 8.1 \%$ ) ]
(4) In 126 cases of 33 clinical trials 68 deviations were found. The following serious deviations were observed: out of exclusion/inclusion criteria, inappropriate timing of informed consent, and omission of evaluation.

(5) Data errors observed in this survey were considered to be within the acceptable range.

We conclude that by reviewing the verification rate, the inconsistency rate and occurrence state of deviation as measurements of quality of clinical trial data, a medical institution can achieve their own data management. It should be noted that the investigational physician has the responsibility of completing an official medical chart of each patient as the physician's own data management.

We gratefully thank the monitors concerned in this survey for their earnest cooperation.

\section{References}

1) Dixon, J. R. Jr. : The international conference on harmonization good clinical practice guideline. Qual. Assur., 6 : 65-74 (1998).

2) Ohashi, K., Osuga, E., Atarashi, H., et al. : Resea$\mathrm{rch}$ and analysis of problems of the direct access in the practice of monitoring or audit. Jpn. J. Clin. Pharmacol. Ther., 29:457-470 (1998) (in Japanese).

3) Schuyl, M. L. and Engel, J.: A review of the source document verification process in clinical trials. Drug Information J., 29 : 1291-1299 (1995).

4) Hilner, J. E., McDonald, A., Van Horn, L., et al. : Quality control of dietary data collection in the CARDIA study. Control. Clin. Trials, 13:156159 (1992).

5) Clarke, P. A. : Data validation. Rondel, R. K., Varley, S.A. and Webb, C.F. (Ed.) : Clinical Data Management, John Wiley \& Sons, Ltd., Chichester. New York. Brisbane. Toronto. Singapore, pp. 189-212 (1993).

6) Rondel, R. K. : Quality assurance and clinical data management. Rondel, R. K., Varley, S. A. and Webb, C.F. (Ed.) : Clinical Data Management, John Wiley \& Sons, Ltd., Chichester. New York. Brisbane. Toronto. Singapore, pp. 229243 (1993). 